IRA-International Journal of Technology \& Engineering

ISSN 2455-4480; Vol.03, Issue 03 (2016)

Institute of Research Advances

http://research-advances.org/index.php/IRAJTE

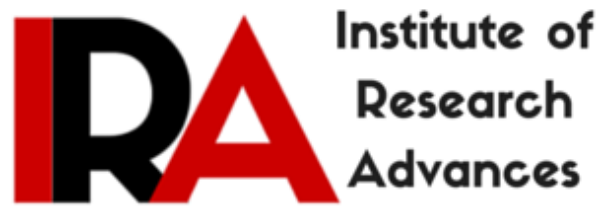

\title{
Inter-Basin Water Transfer Impact Assessment on Environment of Pennar to Cauvery Link Canal
}

\author{
S. V. J. S. S. Rajesh ${ }^{1}$, B. S. Prakasa $\operatorname{Rao}^{2} \&$ K. Niranjan ${ }^{3}$ \\ ${ }^{1}$ Dept of Physics,WISTM Engineering College, Visakhapatnam-531173. \\ ${ }^{2}$ Dept of Geo-Engineering, Andhra University, Visakhapatnam-530003. \\ ${ }^{3}$ Dept of Physics, Andhra University, Visakhapatnam-530003.
}

DOI: $\underline{\text { http://dx.doi.org/10.21013/jte.v3.n3.p8 }}$

\section{How to cite this paper:}

Rajesh, S., Rao, B., \& Niranjan, K. (2016). Inter-Basin Water Transfer Impact Assessment on Environment of Pennar to Cauvery Link Canal. IRA-International Journal of Technology \& Engineering (ISSN 2455-4480), 3(3). doi:http://dx.doi.org/10.21013/jte.v3.n3.p8

(C) Institute of Research Advances

\section{(cc) EY-NO}

This works is licensed under a Creative Commons Attribution-Non Commercial 4.0 International License subject to proper citation to the publication source of the work.

Disclaimer: The scholarly papers as reviewed and published by the Institute of Research Advances (IRA) are the views and opinions of their respective authors and are not the views or opinions of the IRA. The IRA disclaims of any harm or loss caused due to the published content to any party. 


\section{ABSTRACT}

Owing to its striking differences in its climatic conditions, India is frequently facing with extremities such as heavy rain fall in some regions where as some other regions endure little rainfall. The regions receiving heavy precipitation are facing floods resulting in huge amount of water runs into the sea. Contrarily, the regions, without adequate rainfall are suffering from persistent droughts. To overcome such disparities in the distribution of water, National Water Development Agency (NWDA) put a proposal to transfer water through link canals between rivers. The current study is limited to two river basins, Pennar and Cauvery. The present study is confined to Pennar (somasila) to Cauvery (Grand Anicut) whose length is $483 \mathrm{~km}$. The study consist of $10 \mathrm{~km}$. buffer on either side of the canal and it occupies 17,215.68 sq. km. out of these 10,105.96 sq.km.is proposed command area which falls in Chittoor, Chengalpattu, North Arcott and South Arcott districts.

Using IRS-P6, LISS-III data the characteristics of the rocks, lineaments, drainage, settlements and land use/land cover are mapped for better analysis and the environmental impact. The study indicated that Current fallow land of $5340.14 \mathrm{~km}^{2}$ and $6307.98 \mathrm{~km}^{2}$ of cropland will be brought under cultivation which is more than what is NWDA estimated land that will be benefited. The canal will provide water for irrigation and drinking to 4597 villages and 244 villages to be rehabilitated. 119 culverts/canal bridges and 24 aqueducts have to be constructed across the canal.

Key Words: Link canal, Land use/ Land cover, Remote Sensing, Lineaments.

\section{Introduction:}

In today's world, water emerged a very vital resource for the existence of life on the planet earth. To provide support to the life of flora and fauna, water is quintessential. Water scarcity impacts not only the plant and animal life but also it may lead to conflicts between states and countries. Owing to ever increasing pressure of population on land for meeting the growing demand for food, fuel and fiber, a sizeable area of erstwhile barren, fallow and marginal lands and forests in the country has been brought under cultivation. [1]

To overcome the growing demand for water, there is a need of harvesting the same. Increasing Population alongside river basins causes a greater increase in the demand for water for agriculture, industrial and basic needs. The surplus water areas suffer with floods and deficit areas face droughts and famines. To avoid all these problems it was conceived that if water could be transferred from surplus region to the demanding one, it may prove to be of greater use to meet the demand for water, particularly in urban areas. That is why the linking of rivers with the help of canals has been put forth so as to provide water to the population deprived of this most important source of life. Inter basin transfer of water is not a new concept. ${ }^{[2]}$ The concept of interlinking of rivers in India was brought forward in 1973 for the first time stating that the Perennial rivers of the Himalayas could be linked with the Peninsular rivers on the Southern part of India so that every part of the country is provided with water not only for human needs but also for agriculture and industrial needs. Many a researcher

discussed on harvesting excess water in a basin and its pros and cons at length . ${ }^{[3-16]}$ However National Water Development Authority (NWDA) foresees that interlinking of river basins must be carried out not just to meet all the water demands but also for sustaining sub-surface water reserves in a healthy condition. 
The Pennar (Somasila) - Cauvery (Grand Anicut) link Canal study area falls in Nellore and Chittoor districts of Andhra Pradesh, Tiruvallur, Kancheepuram, Vellore, Tiruvannamalai, Villupuram and Cuddalore districts of Tamil Nadu and Pondicherry. The existing sources of irrigation are mainly seasonal tanks and wells/dugwells in the study area. Experts argued over the issue both in favor and against the concept. Intellectuals who supported the linking of rivers stated it is unavoidable whereas those who opposed the concept quoted "it is not much useful considering the expenditure that is to be incurred on such projects". Information on land use/land cover provides a better understanding of the cropping pattern and spatial distribution of fallow lands, forests, grazing lands, wastelands and surface water bodies, which is vital for developmental planning. ${ }^{[17-18]}$ In view of the pressure exerted by increasing population, need for mitigating increasing demand of land resources, appropriate scientific land-use planning and land management strategies could provide the alternative for the sustainable development of any region. ${ }^{[19]}$

It is appropriate to use powerful methodology such as GIS combined with Remote Sensing to make the planning of use task of interlinking of rivers easier and effective. ${ }^{[20]}$ Many investigations were done with Remote Sensing \& GIS inputs for studying various land features and the changes. ${ }^{[21-27]}$

This information is also vital to oversee, design the Land use and for detecting the changes in the environment as well. Remote sensing and GIS are effective's tools for land cover and vegetation mapping. ${ }^{[28]}$ Various techniques of remote sensing, digital image processing are discussed in. ${ }^{[29]}$ The observation of the physical cover that includes vegetation both natural and planted is defined as Land cover.

An attempt is made in this study so as to map out the Land use/Land cover in order to obtain comprehensive information about the potentials and limitations of the uses of the present study area. The attempt is also towards understanding the environmental impact of the project on the present study area. Assessment of environmental impact is considered very crucial at the early stages of planning of irrigation projects to identify expected negative impact and ways to subdue the problem. Many river channeling projects which have the bases and measures adopted correspondingly in order to protect the ecosystem and human rehabilitation. With the growing population such type of projects and inter linking of rivers are essential for domestic and development of food grains. ${ }^{[30-32]}$

The total diverted water of $8565 \mathrm{Mm}^{3}$ from the Somasila dam is proposed through the link to meet command area enrooted $\left(3048 \mathrm{Mm}^{3}\right)$. Other than this the total domestic and industrial water requirement of the area $\left(1105 \mathrm{Mm}^{3}\right)$, transmission losses $\left(557 \mathrm{Mm}^{3}\right)$ and Transfer to Cauvery $\left(3855 \mathrm{Mm}^{3}\right)$. The areas under each of the branches so measured were adjusted to match with the gross command area of 840,218 ha., after deducting the forestland.

\section{Study area:}

The study area of the Pennar (Somasila) - Cauvery (Grand Anicut) link canal occupied 17,215.68sq.km.including command area. It is covered in 53 SOI sheets of 1:50,000 scales. The canal is bounded between $10^{\circ} 43^{\prime} 57^{\prime \prime} \mathrm{N}-14^{\circ} 366^{\prime} 52^{\prime \prime} \mathrm{N}$ latitude and $78^{\circ} 44^{\prime} 2^{\prime \prime} \mathrm{E}-80^{\circ} 18^{\prime} 12^{\prime \prime} \mathrm{E}$ longitude. Figure-1 shows the link canal (Center line), study area buffer of $20 \mathrm{~km}$. on both sides and the proposed command area. 
The annual rainfall in the command area varies from 635 to $1019 \mathrm{~mm}$. The Pennar - Palar - Cauvery Link Project lies in Andhra Pradesh and Tamil Nadu states. The existing Somasila dam is located just downstream of the confluence of Cheyyeru River and Kallettivagu River with Pennar River. Grand Anicut is located on the border of Tiruchchirappalli and Thanjavur districts of Tamil Nadu.

The study area consists of out- crops of Cuddapah super group of rocks, unclassified crystallines, rocks of Archean group along with rocks of Undividied Dhalwar group (Ar) and Mesoic-Cainozoic rocks (ep Pc).

\section{Methodology:}

The proposed river link map of the peninsular component downloaded from NWDA department site http://nwda.gov.in/nwda/proposals/ feasibility in jpg format. The link canal alignment map is geo-rectified before demarcation of study for the link. In GIS a buffer zone is created at a width of $10 \mathrm{~km}$. on either side of the alignment to extract effective study area enroot including the command area under the present link for study. The shaded part of the figure represents the command area. Prior to digitization the SOI maps have been geo-referenced in polyconic projection system with a scale of 1:50,000. After the geo-reference the maps have been registered to real world co-ordinates using ERDAS IMAGINE 9.1software. Total 53 topo-sheets are rectified and prepared a subset as per the study area polygon. A topo-sheet mosaic is prepared for all the maps which fall in the study area. From this mosaic image, study area is extracted using shape file in the software. LISS-III images of IRS-P6 satellite data are Geo-registered utilizing SOI data base. The study includes geology, rocky out crops, drainage, road network, settlements, Land use Land cover and lineaments with remote sensing data update in detail for the link canal. The mosaic of LISS III data information is given in the table-1. The remaining images are projected based on the rectified image.

\section{Drainage}

The drainage of the study area is extracted through onscreen digitization from the toposheet mosaic. The drainage includes streams, canals, tanks and reservoirs which are covered in the study area of the link canal (figure 2).

Besides the drainage study along the alignment, major Nala, Canal and River crossing are noted and described, with reference to their location. Alignment starts near Nellore and passes through a major tank before it enters Rapur mandal. In Rapur, the alignment crosses vagu systems at 10 locations before it enters Dakkali mandal. In Dakkali,the canal crosses Pedda kona vagu, Chinna kona river besides Alapaleru river at $52 \mathrm{~km}$. In Venkatagiri also it crosses Biragundlu kaluva and Devara kona. In Srikalahasti alignment crosses Marrimanu kona, Repalli kaluva, Varlapudi kaluva and Uppu Kona. Beyond this point, it enters Renigunta where it crosses Tummuru kona, Ralla kaluva and Swarnmukhi river in Yerpedu. In Pallippattu canal crosses Nagari river at $139 \mathrm{~km}$. Nandi river is crossed by the canal at $156 \mathrm{~km}$ in Tiruttani taluk. In Arakkonam, Kallar river is crossed by the canal at $178 \mathrm{~km}$. Vegavati river and Palar rivers are cut across by the canal in Kanchipuram taluk. At $222 \mathrm{~km}$ alignment crosses Cheyyar river in Cheyyar and Suka nadi in Vandavasi taluks. In Gingee alignment crosses Varaha nadi at $276 \mathrm{~km}$, Ponnaiyar river, Gadilam river and Sesha nadi and a few major tanks are crossed by the alignment in Tiruekkovilur taluk. Manimukha nadi in Kallakkurichchi taluk and Gomukha nadi and Velar river in Vriddhachalam taluk are cut across by the canal. Chinnar river is crossed by the alignment at $390 \mathrm{~km}$. Anaivari oda in Perambalur, Anaivari river, Kallar river in Ariyalur and Marudaiyar, Nandiyar and Kulaiyar rivers in Lalgudi are traversed by the 
canal before joining Cauvery river at Lalgudi village. The river crossing points of the link canal data given in the table- 2 .

\section{Settlements}

An attempt is made to demarcate all the villages in the study area along with attribute data in Arc GIS. While studying villages in the area with reference to administrative boundaries, the command area polygon data is overlay on the topo-sheet mosaic. From the topo-sheet mosaic settlements are extracted in Arc GIS environment. All the villages are marked as point data which fall within the corridor of the link and the command area.

The link canal starts near Yenkatareddipalli village in Kaluvoya mandal of Nellore district in Andhra Pradesh. From this point it passes through five mandals in Nellore district touching number of villages in these mandals. Then it enters the district of Chittor where it goes through a good number of mandals and villages, before entering Tamilnadu. It enters Tamilnadu at kottainadu village in Palipattu mandal of Chengalpattu district. Only a part of Chengalpattu district falls directly under the canal area, whereas a number of villages fall under the study area.

After thatThe canal enters the village of Ramasamudram in Palipattu taluk of Chengalpattu district and passes through number of villages. The density of villages is very high in this section. Then it goes to the North Arcot district entering at Bodinayakankandigai village in Arakkonam taluk. The density of villages in this region also is very high but slightly less when compared to that of Chengalpattu. The canal once again passes through the districts of Chengalpattu and North Arcot respectively and then penetrates South Arcot district at Singanikuppam village of Tindivanam taluk.

the canal enters at Pudur village in Tirukkovilur taluk in the district of South Arcot. The number and the density of the villages is very high in this phase also covering large amount of the study area. The canal then enters the district of Tiruchirapalli and Perambalur taluks. The density of villages here is moderate and as the canal progesses in to the district of Thanjavur that the density of villages is very less.

Buffer area if $1 \mathrm{~km}$ is created in Arc GIS around the alignment of the link canal to identify the villages falling within the buffer area. All the villages covered within the buffer area are deemed to be affected villages during the construction. There are 244 villages coming under the buffer area which have got to be rehabilitated either fully are partially. There are four villages in Nellore district, 34 villages in chittoor district, 45 in Chengalpattu, 53 in North Arcot, 63 in South Arcot and 45 villages in Tiruchhirapalli falling under the buffer area.

\section{Road Network}

The roads in the study area of the canal are mapped through onscreen digitization from the topo-sheet mosaic. The study includes highways, metal roads, unmetal roads and foot paths. The road network is shown in figure 3. Topo-sheet mosaic is taken in Arc-GIS and canal alignment and buffer of the study area boundaries are overlay on it to digitize the roads and intersection points with alignment. The interesting points of canal alignment with all type of roads are marked and tabulated with the distance parameter.

The canal starts from Pennar near Baddevalu and passes through $10 \mathrm{~km}$ in Kaluvoya and enters Rapur mandal where it crosses 6 major roads and a few minor roads. 
After Rapur canal covers a few kilometers in Renigunta and Yerpadu mandals and $20 \mathrm{~km}$ in Puttur mandal. The canal crosses 7 major roads and railway line at $100 \mathrm{~km}$ point. After Puttur canal enters Pallur and Tiruttani mandals and crosses 7 major roads and number of minor roads for a length of $22 \mathrm{~km}$. After Tiruttani the canal enters Arakkonam and Kancipuram taluks for a distance of $36 \mathrm{~km}$ where it crosses 11 major roads before it enters Cheyyar at $213 \mathrm{~km}$. The canal crosses railway line at $195 \mathrm{~km}$ and 6 major roads in Cheyyar. After Cheyyar, canal passes through Vandavasi and crosses 8 major roads before it enters Tindivanam. At $274 \mathrm{~km}$ canal passes through Gingee and Viluppuram taluks where it crosses 11 major roads number of minor roads. After Viluppuram canal passes through $40 \mathrm{~km}$ distance in Tirukkovilur taluk and crosses 10 major roads and a number of minor roads. After Tirukkovilur link canal passes through Kallakkurichchi and Vriddhachlam taluks where it crosses 10 major roads and a number of minor roads. At $384 \mathrm{~km}$ canal enters Peramballur taluk where it crosses 6 major roads before it enters Ariyalur. In Ariyalur canal cut across many major roads (22) with in a distance of $37 \mathrm{~km}$. After Ariyalur it enters Lalgudi taluk and crosses 10 major roads before joins Cauvery River. The canal cut crosses a railway line at $455 \mathrm{Km}$ and another railway line at 476 $\mathrm{Km}$. The metal/unmetal roads crossing points of the river shown in the table -3 .

\section{Geology}

An attempt is made to study the geological formations in the study area and describe their occurrence along the alignment. The geological map of the state is obtained in JPJ format and the map is scanned, geo-referenced and digitized various geological formations as separate polygons in Arc GIS. The study area, alignment and district boundaries are superimposed on the map and described geological formations with respective to location and distance.

The study area of the link canal is a part of Eastern Ghats Super Group. The study area in the Karimnagar district is occupied with Lower gondwana system of rocks and small part by Upper gondwana system. About $70 \mathrm{~km}$ the canal is in Nellore district where the area occupied by Cuddupah super group of rocks and Unclassified Crystalline of Archean age. In Chittor district the major part of the study area of the canal is occupied by Unclassified crystallines of Archean age. A small part of the area is covered with Cuddapah super group of rocks. In North Arcot the canal runs about $72 \mathrm{~km}$ where the study area is occupied by Undivided Dharwar system of rocks, along the alignment. But the proposed command is mostly occupied by Undivided Vindhyan group of rocks of Mesozoic era. In South Arcot the canal runs about $129 \mathrm{~km}$ where Undivided Dharwar systems of rocks are occupied along the alignment but the command area is with Undivided Vindhyan group of rocks. In Thiruchcharapalli district the entire study area and the canal alignment is occupied with Undivided Vindhyan group of rocks (Figure 4.).

\section{Remote sensing}

Over the years, remote sensing has been used for land use/land cover mapping in different part of the India. ${ }^{[33-40]}$ LISS-III Sensor data of IRS-P6 can be used to carry out the detailed Land use Land cover information. ${ }^{[41]}$ 


\section{Visual land use classification for LULC}

The visual interpretation has been carried out based on the data acquired from standard FCC (False color composite) imagery of IRS-P6, LISS-III for land use and land cover. The land use and land cover are interpreted separately putting into use the interpretation keys. Then the ground truth information is obtained taking into consideration the scheme drawn previously and traverse plan. The ground data has been collected as per the stipulated Performa so that a minimum of $10 \%$ of the specified area is covered. The areas which were doubtfully interpreted at the preliminary stages have been verified specifically. Basing on the data of ground truth, the changes have been effected and classes along with the boundaries have been refined after which the estimation of areas falling under different classes (figure 5.) has been carried out using planimatric measurements so has to fulfill the statistics of stipulated land use.

Crop Land is indicated in bright red to red in colour, although the shape and size vary from place to place. The total crop land is $6307 \mathrm{~km}^{2}$ in the study area whereas the command area comprises of $4336 \mathrm{~km}^{2}$ of the total area of cropland. Current Fallow is an agricultural land which is taken up for cultivation but is temporarily allowed to rest, uncropped for one or more seasons, but not less than one year. These lands are appeared in light red to cyan in colour with varying shape size in the study area. An area of 5340.14 sq.km is occupied by these lands throughout the study area out of which 2907 sq.km. falls in the command area of the canal. Forest areas appear in dark red to red of different sizes. The area of forests in the study area is precisely 2965sq.km. Approximately 895sq.km.of forest land falls in the command area. Water bodies include Reservoirs, lakes, tanks, canals besides natural lakes, rivers and streams and creeks. These are indicated in blue to dark blue color basing on the depth of the water body and turbidity. They occupied an area of $1322.35 \mathrm{sq} . \mathrm{km}$ in the study area wherein about 1048 sq.km. of water bodies come under the command area. Most of the water bodies are irrigated tanks. The Scrubland is described as a forest where the vegetative density is less than $20 \%$ of the canopy cover. Scrub lands, basing on the moisture cover on the surface, appear in light yellow to brown and greenish blue. Scrub lands occupy an extent of 400sq.km approximately in the study area.

Built-up land is an area of human habitation developed due to non-agricultural use and that has a cover of buildings, transport and communication, utilities in association with water, vegetation and vacant lands. They appeared in light brown to cyan colour. An area of $457 \mathrm{sq} . \mathrm{km}$ approximately is occupied by built up land in the study area. Sandy areas are the areas which have stabilized accumulations of sand in-situ or transported in coastal, riverine or inland (desert) areas. They appear in white colour. The total area of sand in the study area is $29.75 \mathrm{sq} . \mathrm{km}$. Plantations are under agricultural tree crops, planted adopting certain agricultural management techniques. It includes tea, coffee, rubber, coconut, areca nut, citrus fruits, orchards other horticultural nurseries. They appear in dark red to red of different sizes. They also be identified based on association property. The remaining land use categories are treated as miscellaneous because of their nature of occurrence, physical appearance and other characteristics. It also includes linear features, rail and roads in the study area. The study area comprises to an extent of 338.82sq.km under this class. 


\section{Lineaments}

LISS-III image mosaic is taken in Arc GIS and study area buffer is overlaid on the image. Geological lineaments/fault zones are identified and mapped through on screen digitization. This study is limited to the link canal study area.

The canal alignment in Nellore district passes through hilly terrain where regional strike is mostly parallel to the alignment. Here 9 lineaments are mapped and all of them are intersecting the alignment in perpendicular direction. Chittoor district is also covered by hilly terrain and the strike of the formation is parallel to the alignment. Here 10 lineaments are identified and all of them are intersecting perpendicular to the alignment. There are 2 lineaments each from Chengalpattu and North Arcot districts of the study area and one from South Arcot district. The study area of Tiruchcharapalli indicated 5 lineaments and all of them are intersecting with the alignment. 8 more lineaments are taken from the map which is prepared by Ganapathy (2010).

\section{Alignment modification}

The canal alignment is over laid on the toposheet mosaic of the study area and the image. The alignment direction is examined closely with topographic features, hilly terrain, croplands, settlements and reserved forest. Accordingly changes in the alignment are suggested at 10 locations. These locations are shown in the Figure 6.in two parts for clarity of display. A change in the direction of the canal is suggested near Kothurupalle village in Koluvoya mandal to bypass forest area which crossed by the original alignment $(26.3 \mathrm{~km})$. Another change in the alignment is

suggested from Alturupadu village to Palerukota $(7.3 \mathrm{~km}$.) in Venkatagiri mandal. A similar diversion is suggested at Devaru kona to Kuntakalva (9.11k.m.).

The original alignment is cutting across Velikonda hill and Krishnapuram protected forest, hence a diversion is suggested from uppukonda near Gollapalle village in Srikalahasti mandal and at $140 \mathrm{~m}$ contour to join at Vikrutamala village in Yeripedu mandal (28.88k.m.). In Narayanavanam mandal the original alignment is through Narayanavanam reserved forest, hence a change in the direction of the alignment is indicated from Suddakaka village to Ramakrishnapuram (12.73k.m.). The alignment again cut across hilly terrain (400 m elevation) near Krishna Samudram and hence a change in the alignment direction is put forth from Krishna Samudram to Pentakandigai (12.75k.m.) in Chengalpattu taluk. The original alignment passes through Arakkonam town hence a small change in the direction is suggested from Kaimur village to Perumuchchi (5.88k.m.). Another small diversion is taken to bypass 3 villages and joins original alignment at Pullalur $(3.3 \mathrm{k} . \mathrm{m}$.) village. A similar change in the alignment is shown to bypass 3 more villages from Katteri village to Kalpakkam village.

Finally by modifying the alignment it is noted that 21 villages are being bypassed. The modification effects save approximately 39sq.km. area of reserved forest which was to be lost with the prior alignment. Hilly terrain of 58sq.km.area remains intact due to the modification and the burden of cutting and flattening of this terrain can be saved which proves to be cost effective for that reason.

\section{Environmental Impact}

The environmental impact due to the canal alignment is both advantageous as well as disadvantageous. 
The canal will be beneficial to about 4597 villages to supply drinking water alongside recharging the ground water levels and providing an additional source of irrigation. Remote sensing study elucidates that a large extent of area of about 5340 sq.km falls under Current fallow land class. With the advent of the canal all this Current fallow land can be irrigated and additional water can be supplied to those lands in which single crop is formed due to inadequacy of water for double crop. It is $1,164,812$ ha derived from the real time data as against the NWDA projections of 840,218 ha. Out of $484 \mathrm{~km}$ of canal length, $217 \mathrm{~km}$ is through unclassified crystalline rocks. It will be useful to avoid the seepage zones while constructing the canal.

There are about 244 villages which will be impacted by the canal along its length of $483 \mathrm{~km}$ also there are 5 tribal villages in the course. For a length of $81 \mathrm{~km}$, the canal runs through hilly area. About 112.36 sq.km of forest canopy will disappear because of the canal construction. About 149 sq.km area of crop land will be affected in the plains due to alignment of the canal and its water longing.

\section{Conclusion}

The present study describes the Pennar to Cauvery link canal, which is proposed by National Water Development Agency (NWDA). The present study confined to $10 \mathrm{~km}$ buffer area on either side of the alignment and the proposed command area is 10,105.96 sq.km. The total study area is $17,215.68 \mathrm{sq} . \mathrm{km}$. The study reveals that 4597 villages will be benefitted with drinking water and facilitated with irrigation source. IRS-P6, LISS-III data disclosed that current fallow land of 5340sq.km can be transformed into productive land. The demarcation of the drainage revealed that the total length of the canal cuts across 24 river basins, comes into touch with 10 tanks where as it traverses 25 streams and streamlets. The alignment crosses 119 major roads and number of minor roads alongside some railway lines. Most of the command area is covered by undivided crystalline groups of Mesozoic era. The major part of the study area covered by Undivided Dharwar Archean group of rocks. There 32 lineaments that are being crossed by the proposed link canal. By modifying the alignment it is noted that 21 villages are being saved. The modification effects save approximately 39sq.km.area of reserved forest which was to be lost before the alignment was modified. Hilly terrain of $58 \mathrm{sq} . \mathrm{km}$.area remains intact due to the modification and the burden of cutting and flattening of this terrain can be saved which proves to be cost effective for that reason.

\section{Acknowledgements}

The authors are grateful to Dr.Neeli Srinivas and Dr. N. Bhaskar for their support to carry out the work. Second author extends his thanks to UGC for the award of Emeritus fellowship during 2014-2016. 


\section{References}

[1] Rao, D.P. (1999). Remote sensing applications for land use and urban planning: Retrospective and perspective, Proc. ISRS National Symposium on Remote Sensing application for Natural Resources Retrospective and Perspective held at Bangalore from Jan.19-21,1999,pp.287-297.

[2] Rao, K.L., 1975 India’s Water Wealth (New Delhi: Orient Longman).

[3] Reddy,M.S., 2003.Linking of rivers in India, Special volume. Vol. XVI, No.4A. Gujar, B.R., 2003.Interlinking of rivers: A climatic viewpoint. Curr.Sci., 84, $1381-1382$.

[4] Reddy, M.S., 2003.Linking of rivers in India-Retrospect and, Prospect. Journal of applied Hydrology, 16 (4A), 14-30.

[5] Prabu,S., 2003.Inter-linking of rivers-taskforce to look into all aspects.

[6] Radhakrishna, B.P., 2003. Linking of major rivers of India- bane or boon? Curr. Sci., 84, 1390-1394.

[7] Vaidyanathan.A, 2003, Interlinking of rivers I and II.

[8] Vidyasagar Rao, R., 2003. Inter-basin water transfer - A vital necessity but a distant reality, Special volume. Vol. XVI, No.4A.

[9] Gupta, S.K., and R.D.Despande, 2004. Water for India in 2050: first order assessment of available options, Current Science, 86, No.9. pp 1216-1224.

[10] Biyani, A.K. \& Gupta, S.K., 2004. River linking: More a bane, Current. Science, 87, 277-278.

[11] Radhakrishna, B.P., 2004. Man-made drought and the looming water crisis, Current Science,. 87 (1), 20-22.

[12] Sharma, R.K., 2006. Linking Indian rivers. Current Science, 90 (12), 1589.Jain, S.K.., Vijay Kumar.\& Panigraphy.N., 2008. Some issues on Interlinking of rivers in India. Current Science,.95(6), 728-735.

[13] Prakasa Rao,B.S., Vasudeva Rao. P.H.V., Jaisankar, G., Ammineedu, E., Satyakumar, M., \& Koteswara Rao, P., 2010. Intelinking of River Basins: A Mega Harvesting Plan-A Review, J. Ind. Geophys. Union, 14 (1), 31-46.

[14] Rao BS, Srinivas N, Rao NB, Rajesh SV, Pernaidu P. Geological and environmental issues of the proposed link canal (Inchampalli to Nagarjunasagar) of Godavari to Krishna Rivers adopting remote sensing and geographical information system (GIS). Journal of Geology and Mining Research. 2012 May 31;4(4):75-85.

[15] McCornick, Peter. 2014. "India's River Linking Project: The State of the Debate1 Tushaar Shah Upali Amrasinghe” Draft. Accessed November 11.

[16] Lakshmi, A. S., Saran, S., Srivastav, S. K., \& Murthy, Y. K. (2014). Geospatial Modelling Approach for Interlinking of Rivers: A Case Study of Vamsadhara 
and Nagavali River Systems in Srikakulam, Andhra Pradesh.The International Archives of Photogrammetry, Remote Sensing and Spatial Information Sciences, 40(8), 127.

[17] Philip, G. and Gupta, R.A. (1990). Channel migration studies in the middle ganga basin, India using remote sensing data. Int. J. Remote Sensing , 10(6): 11411149 .

[18] Krishna, N. D. R., Westinga. W. and Huizing. H. (1999). Monitoring land cover changes using geoinformatics in some communal lands of Zimbabwe, Proceedings of Intern. Conf. On Geoinformatics: Beyond 2000, dehradun, March 1999.

[19] Saxena, K.G., Rao, K.S. and Kothyari, B.P. (1990). Social forestry in a broad perspective of integrated resource management and sustainable production. International Journal of Ecology and Environmental Sciences. 16: 15-26.

[20] Krishnaveni, M., Prakashvel,J. and Kaarmegham,J., 2003.GIS and visualization capabilities for interlinking of Indian rivers. Map Asia conference 2003.

[21] Lo.C.P., 1981. Land use mapping of Hong of Kong from Landsat Images: an evaluation, Int. J. of Remote Sensing, 2 (3),. 231-252.

[22] Raghav Swamy, V., Goutam, N.C., Rao, D.P. \& Nagaraja, R., 1992. Land Use/ Land cover mapping and monitoring urban sprawl using IRS data. A few examples. In National Resources Management system (NNRMS) (Ed. R.L.Karale), Dept of Space, Bangalore, pp. 120-127.

[23] Civco, D.L. 1993. Artifical neural networks for land cover classification and mapping, International J. of Geographic Information System 7 (2), 173-186

[24] Rao DP, Gautam NC, Nagaraja R, Ram Mohan P (1996). IRS-1C applications in land use mapping and planning. Curr.Sci.,70(7):575-581.

[25] Murthy, K.S.R \& Venkateswara Rao, V., 1997. Temporal studies of Land Use/Land cover in Varaha River Basin, Andhra Pradesh, India, Photonivachak J. of the Ind. Soc. Of Remote Sensing, 25 (3), 145-154.

[26] Weicheng Wu, Eric F, Lambin, Marie-Francoise C (2002). Land use and cover change detection and modeling for North Ningxia, China, Map Asia.pp.288-292.

[27] Gerhand Kemper, Murat Celikoyan, Orhan Altan, Gonul Toz, Carlo Lavalle, Luca Demicelli, RS-techniques for Land use change detection - Case study of Istanbul, http://www.isprs.org/istanbul2004/comm7/papers/154.pdf.

[28] Skidmore, A.K., Wistke Bijker, Karin Schmidt and Lalit Kumar. 1997. Use of remote sensing and GIS for sustainable land management, ITC Journal, 19973/4.pp.302-315.

[29] Lillesand, T.M. and Kieffer, R.W. (1994). Remote Sensing and IMAGE Interpretation, $3^{\text {rd }}$ edition, John Wiley $\&$ sons, Inc.

[30] Ray, S.S., Dadhwal, V.K., \& Navalgund, R.R. (2002). Performance evaluation of an irrigation command area using remote sensing: a case study of Mahi command 
area using remote sensing: a case study of Mahi command, Gujarat, India. Agricultural Water Management. 56, 81-91.

[31] Louis, G.E., \& Magpili, L.M. (2002). Representing inequities in the distribution of socioeconomic benefits and environmental risk. Environmental Monitoring and Assessment, 79(2), 101-119.

[32] Wildlife Institute of India (2003). Ecological, social and hydrological factors affecting the management of wetland systems in Uttar Pradesh, with special reference to Vijaya Sagar and associated water bodies in Mahoba District, Okhala and Associated water bodies in Ghaziabad district, Bakhira Bird Sanctuary and Nawabganj Bird Sanctuary. Final report submitted to Up Forest Department, Wildlife Institute of India.

[33] Gautam, N.C. and Narayanan, L.R.A. (1983). Landsat MSS data for land use/land cover nventory and mapping: A case study of Andhra Pradesh.J. Indian Soc. Remote Sensing, 11(3): 15-28.

[34] Sharma,K.P., Jain, S.C. and Garg, P.K. (1984). Monitoring land use and land cove hanges using landsat images. J. Indian Soc. Remote Sensing. 12(2): 115121.

[35] Rathore, D.S. (1996). Hydrological land use mapping of Narmada basin. Report No. CS(AR)-222. National Institute of Hydrology, Roorkee, 45p.

[36] Tiwari, A.K., Kudrat, M. and Machandra, M.L.(1996). Remote Sensing and GIS: Indispensable tools for regional ecological studies. Tropical Ecology,37(1): 7992.

[37] Palaniyandi, M. and Nagarathinam, V.(1997). Land use/land cover mapping and change detection using space borne data. J. Indian Soc. Remote Sensing, 25(1): 27-33.

[38] Jaiswal, R.K., Saxena, R. and Mukherjee, S. (1999). Application of remote sensing technology for land use/land cover change analysis. J. Indian Soc. Remote Sensing.27(2): 123-128.

[39] Minakshi, Chaurasia, R.and Sharma, P.K. (1999). Landuse/land cover mapping and change detection using satellite data-a case study of Dehlon Block, District Ludhiana, Punjab. J. Indian Soc. Remote Sensing, 27(2): 115-121.

[40] Brahabhatt, V.S., Dalwadi, G.B., Chhabra,S.B., Ray, S.S., and Dadhwal, V.K. (2000). Landuse/land cover change mapping in Mahi canal command area, Gujarat, using multi-temporal satellite data. J. Indian Soc. Remote Sensing, 28(4): 221-232.

[41] Naik, D.R., Bosukonda, S. and Mrutyunjayareddy, K., 2011. Reservoir Impact Assessment on Land Use/Land Cover and Infrastructure-A Case Study on Polavaram Project. Journal of the Indian Society of Remote Sensing, 39(2), pp.271-278. 
Table.1 IRS-P6, LISS III - Data

\begin{tabular}{|c|c|c|c|c|c|}
\hline Satellite & Sensor & Path & Row & Date & Resolution \\
\hline IRSP6 & LISS-III & 101 & 063 & $\begin{array}{c}12 \text {-MAR- } \\
2010\end{array}$ & $23.5 \mathrm{~m}$ \\
\hline IRSP6 & LISS-III & 102 & 063 & $\begin{array}{c}17-\mathrm{MAR}- \\
2010\end{array}$ & $23.5 \mathrm{~m}$ \\
\hline IRSP6 & LISS-III & 102 & 064 & $\begin{array}{c}17-\mathrm{MAR}- \\
2010\end{array}$ & $23.5 \mathrm{~m}$ \\
\hline IRSP6 & LISS-III & 102 & 065 & $15-\mathrm{JUL}-2010$ & $23.5 \mathrm{~m}$ \\
\hline
\end{tabular}

Table.2.Pennar - Cauvery link canal alignment and river crossing locations

\begin{tabular}{|c|c|}
\hline District & Rivers \\
\hline Nellore & $\mathbf{3}$ \\
\hline Chittoor & $\mathbf{3}$ \\
\hline Chengalpattu & 4 \\
\hline North Arcot & 4 \\
\hline South Arcot & $\mathbf{5}$ \\
\hline Tiruchhirapalli & $\mathbf{5}$ \\
\hline Total & $\mathbf{2 4}$ \\
\hline
\end{tabular}


Table 3: Metal roads for cross bridge locations

\begin{tabular}{|c|c|}
\hline District & Metal roads \\
\hline Nellore & 6 \\
\hline Chittoor & 9 \\
\hline Chengalpattu & 5 \\
\hline North Arcot & 26 \\
\hline South Arcot & 35 \\
\hline Tiruchhirapalli & 38 \\
\hline Total & 119 \\
\hline
\end{tabular}




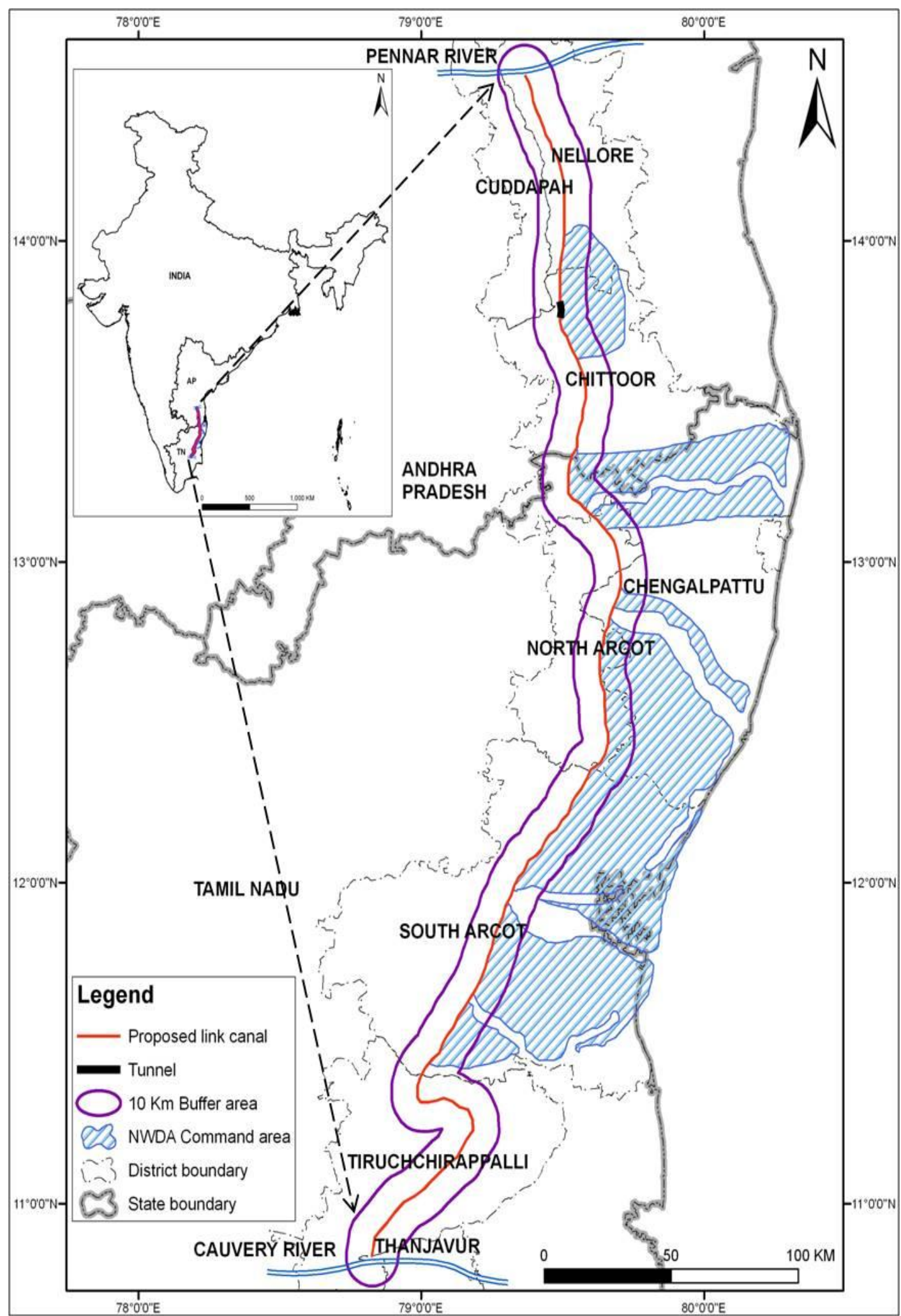

Fig.1.Location map of the study area 


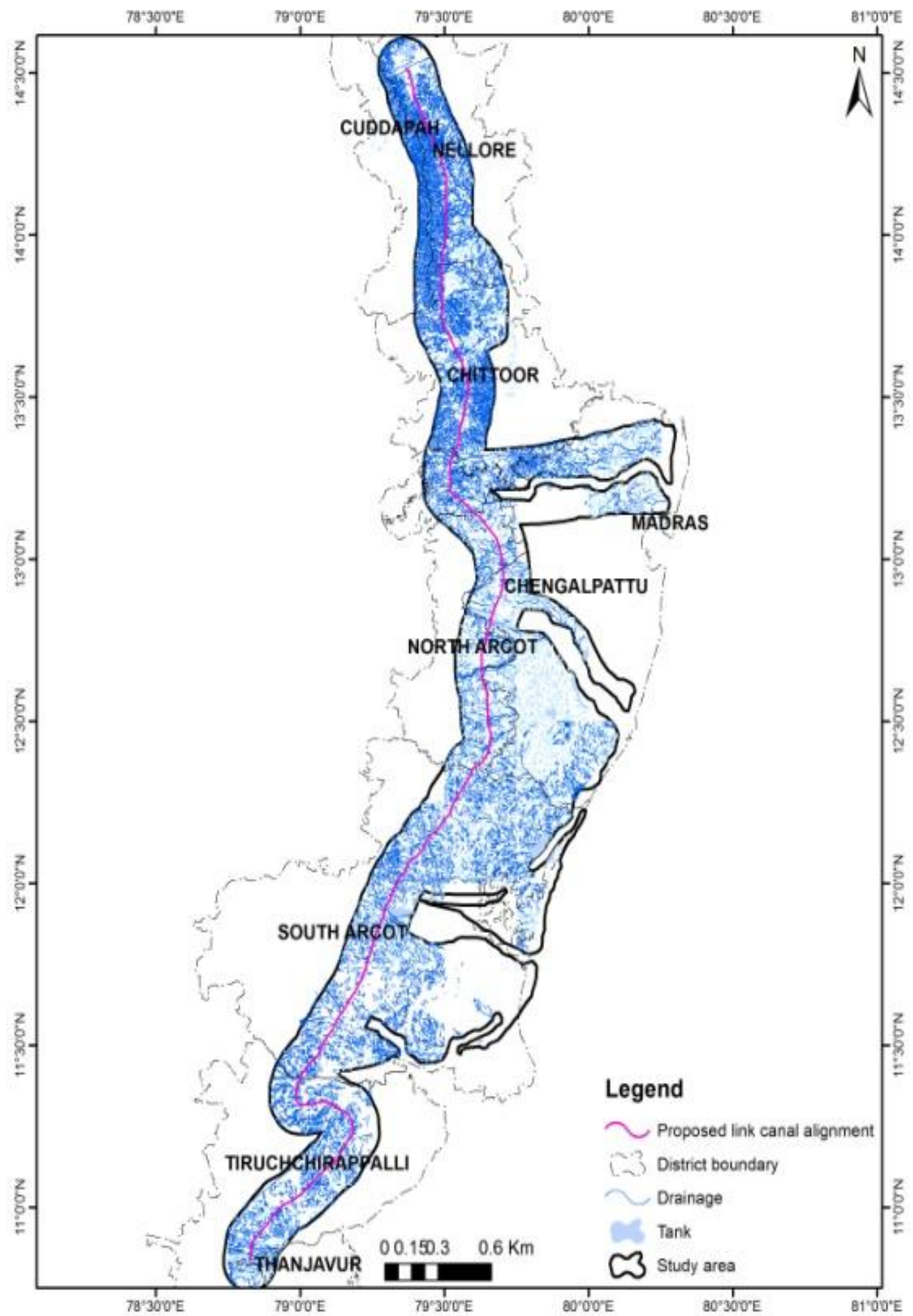

Figure-2 Drainage of the study area 


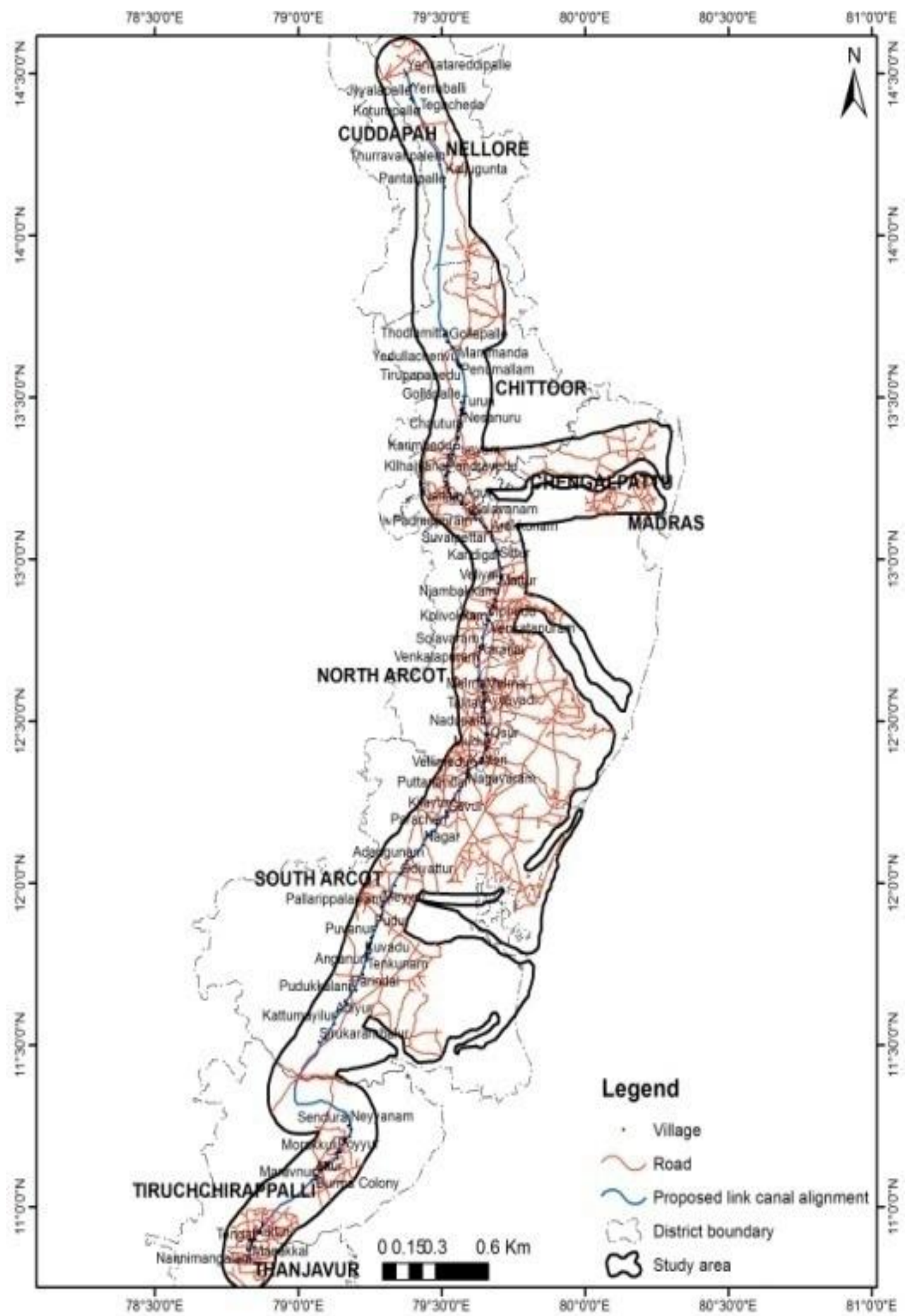

Figure-3 Villages and Road network of the Study area 


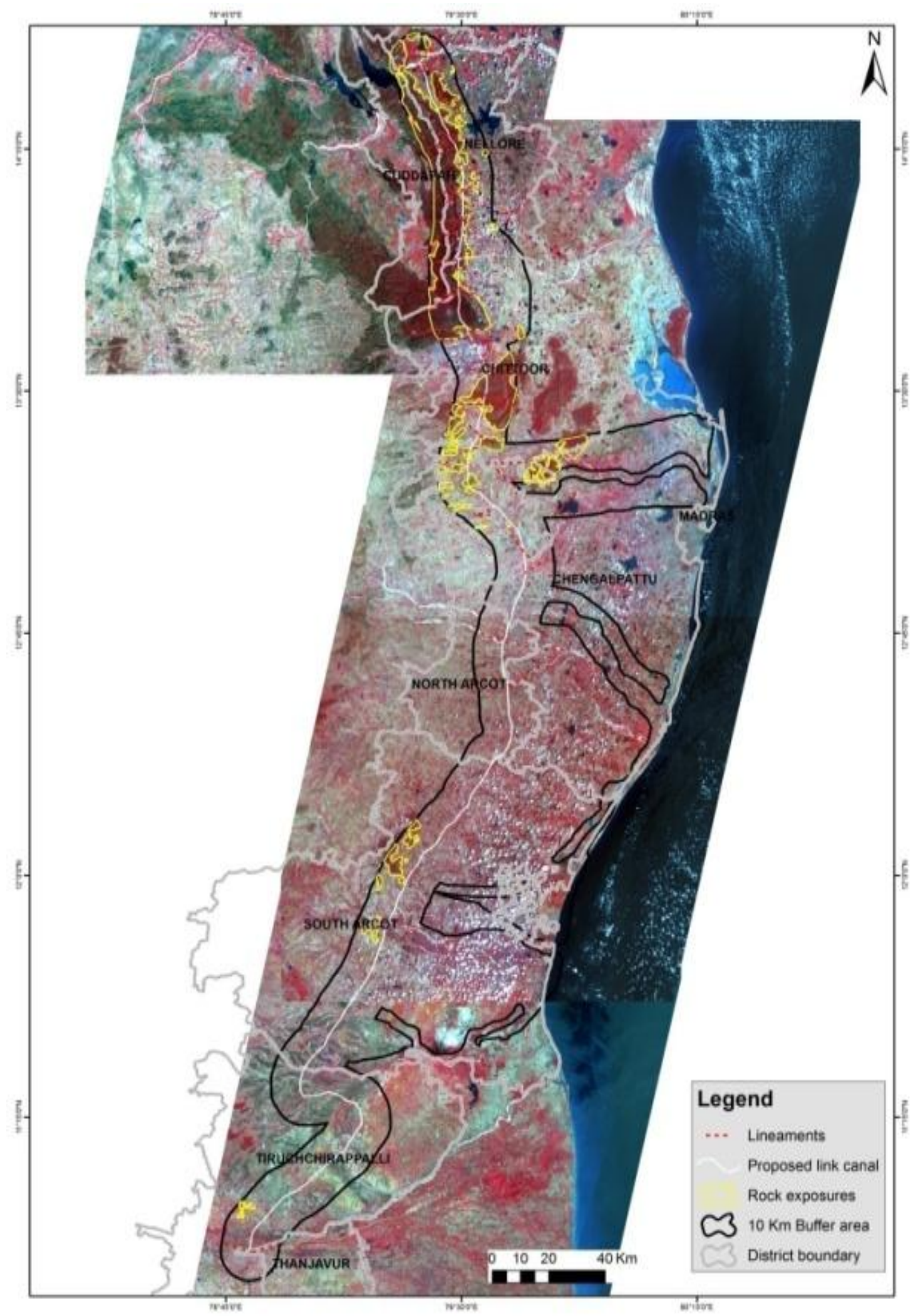

Figure-4 Study area and proposed alignment draped on satellite image mosaic 


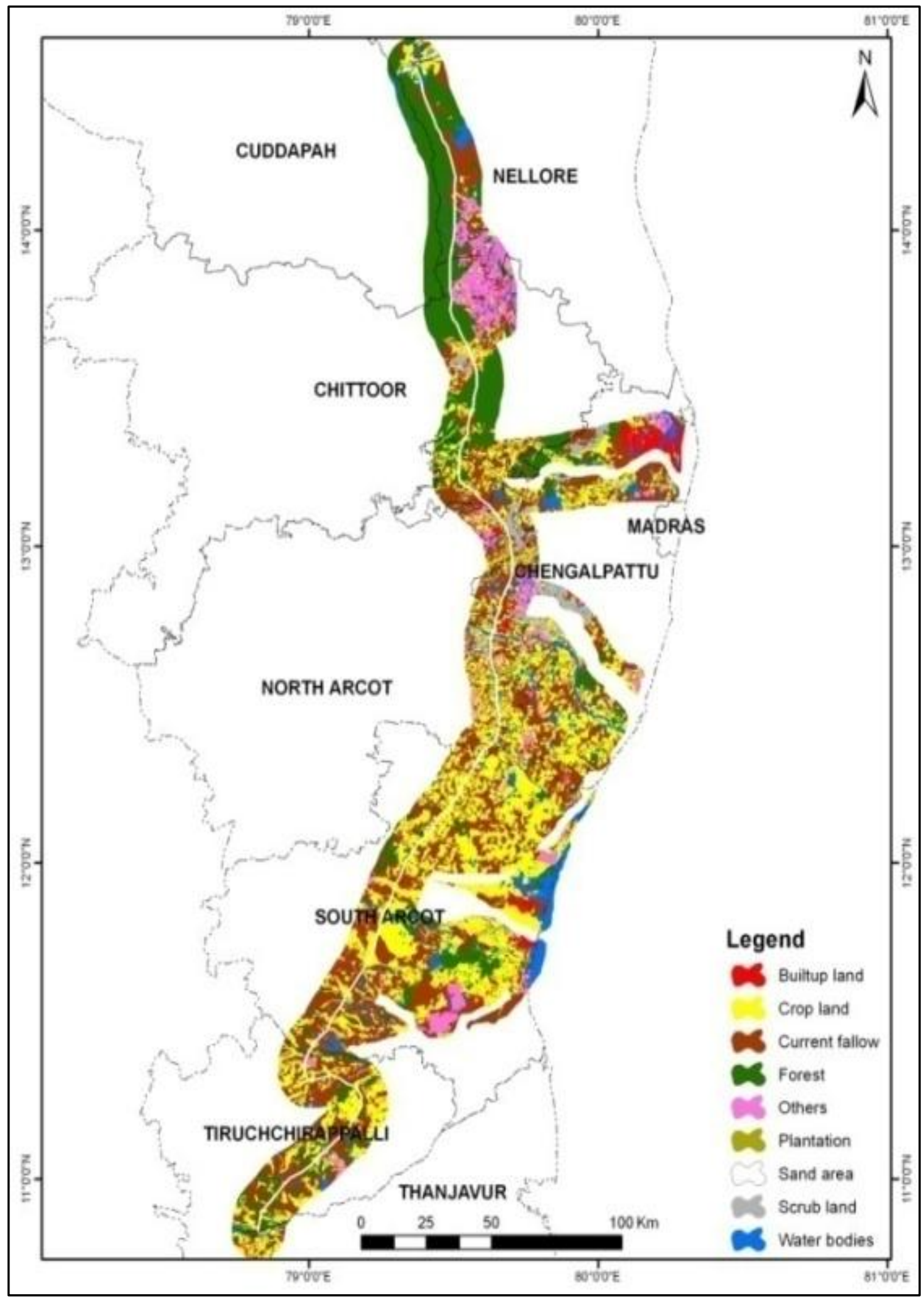

Figure-5 Land use land cover of the Study area 
Figure-6 Alignment modification of the Pennar Cauvery link canal
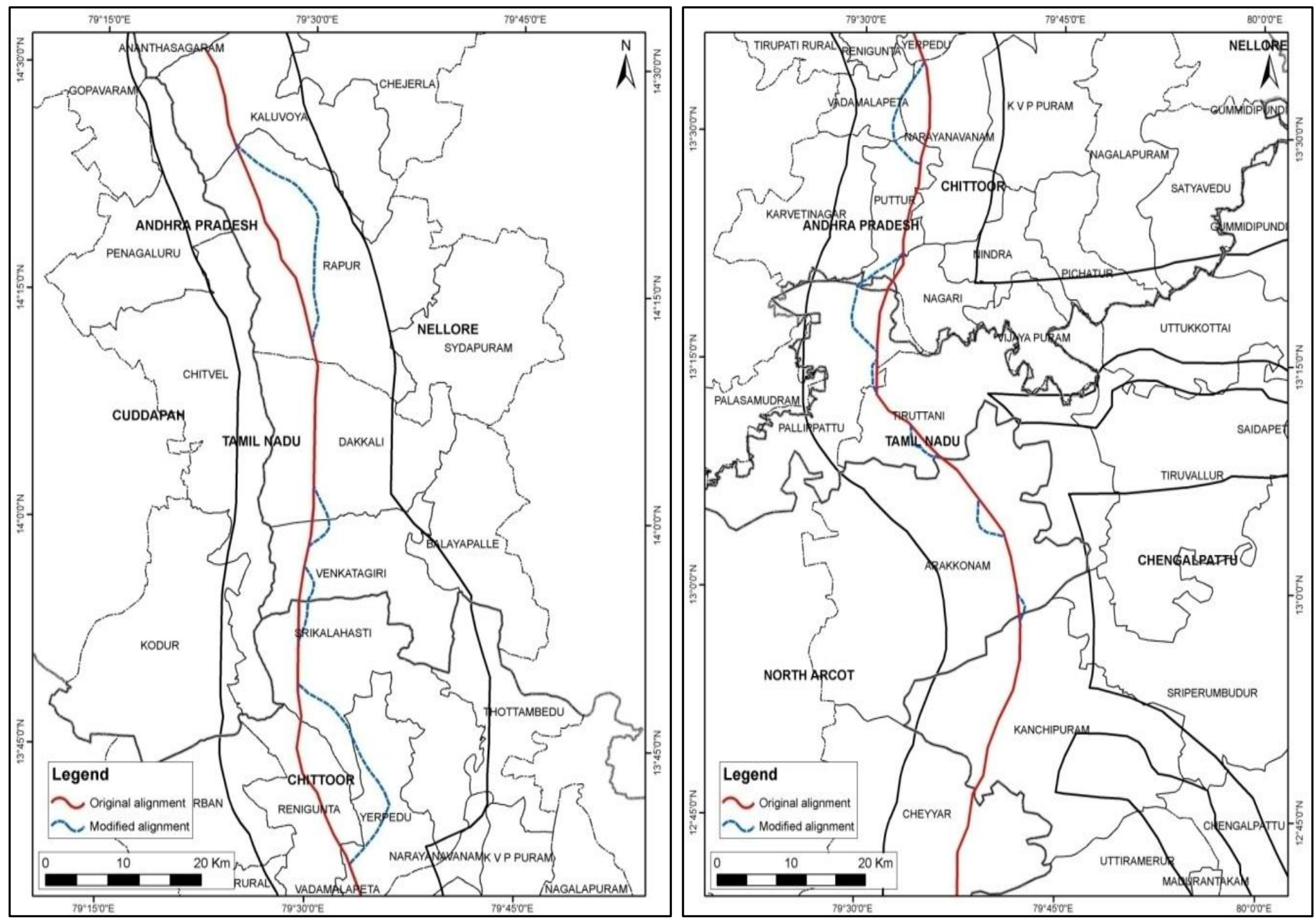